\title{
Identification of Crack Initiation Cause in Pylons Construction of the Excavator SchRs630
}

\author{
Ana PETROVIĆ, Taško MANESKI, Nataša TRIŠOVIĆ, Dragan IGNJATOVIĆ, Momčilo DUNJIĆ
}

Abstract: A crack occurred on gusset plate of pylon vertical truss of bucket wheel excavator (BWE) SchRs630. Numerical calculation model of pylons, slewing platform and undercarriage was formed. Calculations are done using finite element method (FEM) for different load cases. It was determined that the inertial forces caused by bucket wheel boom and counterweight boom masses while breaking slew drive cause the stress concentration in this spot. To complete the whole picture of the structure behaviour dynamic analysis was performed. Based on calculation and distribution of potential and kinetic energy on oscillation modes, using the reanalysis method, redesign of this part of the structure was proposed. The stress was reduced by over $20 \%$ by the proposed redesign solution.

Keywords: bucket wheel excavator SchRs630 pylons; crack propagation; finite element method (FEM); reanalysis; stress concentration

\section{INTRODUCTION}

Bucket-wheel excavator is a high-performance machine that works in difficult working conditions. These machines are the first in the chain of surface coal mining so it follows that the number of failures of these machines should be kept to the minimum possible level. From an economic point of view, the failure of those machines includes a double cost, the cost of repairs and the cost as a result of the fact that the machine does not operate, which is crucial [1].

There are many examples of failure of the bearing structure and mining machinery structural parts [2-8]. The object of observation in this paper is a crack that has occurred on gusset plate of pylon vertical truss of bucket wheel excavator (BWE) SchRs630. Bucket wheel excavator SchRs630 (Fig. 1) is operating at Tamnava East Field, Mining Basin Kolubara since 1995.

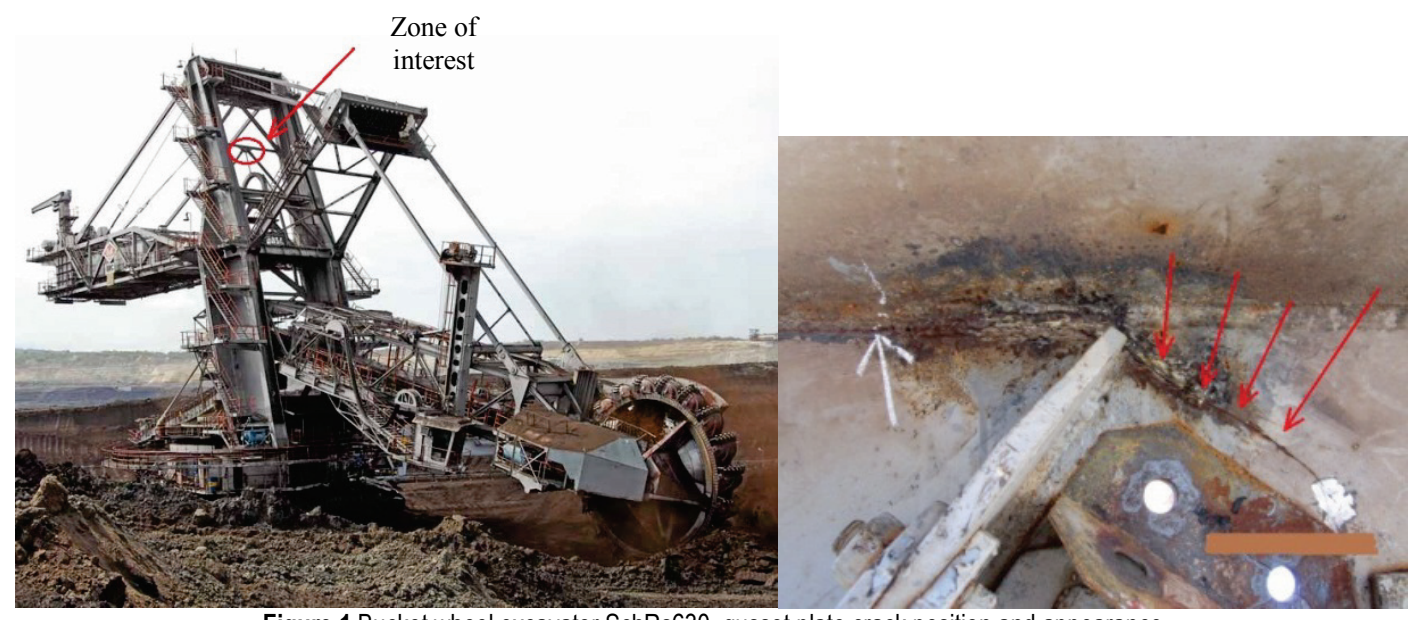

Figure 1 Bucket wheel excavator SchRs630, gusset plate crack position and appearance

In case of failure it is necessary to apply an efficient system for the diagnosis and to perform a number of steps to enable machine to operate $[2,3]$. Firstly, when it comes to failure it is necessary to find the cause of the failure. The cause may be one of four: error in design (geometry) of a part of the structure, error in the production of parts (error in material and welded gussets), error in operation or unpredictable circumstances (unexpected workloads). The samples are taken from the material and tested in order to identify defects in material or welded gussets. Numerical calculation of the structure has to be performed. And if spots with the highest stress concentration coincide with the appearance of cracks leading to failure, it can be concluded that the cause of the failure is poor design solution of the part structure. If this is the case, repair and redesign of that part of the structure has to be proposed. When it comes to redesigning, the redesign proposal should be such as to reduce stress concentration, that it can be done in a short period of time and that it can all be done in the field including minimally possible dismantling of machine parts. In the end, verification of proposed solution must be done.

When conducting numerical calculation and finding causes of failure it should be taken into account that the computational loads are hypothetical and that the results obtained with these loads must be verified. Thus, in the paper [6] the stress state of the elements of the chassis conveyor A2RsB 12500 was analysed numerically and experimentally. Loads were applied by the standards and weak spots of the structure were identified using numerical analysis. Strain gauges were positioned in identified spots. Measurements indicated that the governing force during direction change is even three times higher than the one proposed by the standards.

The significance of the fact that the excavator is a dynamically loaded machine was emphasized in the papers [7, 8]. Thus, the authors of the paper [7], analysing the occurrence of cracks on slew platform of excavator 
SchRs 800 , were able to confirm the weak spots of the structure numerically, but the stress in these spots is not high enough to cause the cracks. However, the acceleration is measured at the identified weak spots and their level proved that calculation loads should be 1,251,5 times higher to obtain a true behaviour of the structure. Authors of the paper [8], taking into account that the loading of the excavator is dynamic (not static), introduce the term "amplitude of stress changes".

Paper [9] represents the verification of importance of calculating the distribution of kinetic and potential energy on main oscillating modes. Reanalysis method is based on the knowledge of this distribution. The reanalysis is the techniques through which is improved the dynamic response of structures to a local repair of the structure bad parts. In this paper are given recommendations on how to redesign a zone depending on relations of kinetic and potential energy. Several proposals to improve the construction of BWE undercarriage are shown in this paper.

\section{FEM MODEL OF THE BWE SchRs630 PYLONS SLEWING PLATFORM AND UNDERCARRIAGE}

The basic procedure in diagnostics of the structure is its computer modelling and the corresponding static and dynamic calculation using the numerical method FEM. FEM is a universal method that can help in solving various problems [2-13].

The software package KOMIPS was developed at the Faculty of Mechanical Engineering in Belgrade [14], which enables modelling and calculation of complex structures and problems.

The most sensitive, the most important and most difficult manageable procedure of the calculation process is structure modelling. Modelling, in fact, is mapping the physical to computational model according to technical documentation, selection of the type or types of finite elements and defining of physical model discretization by finite elements, nodal points, boundary conditions and loads.

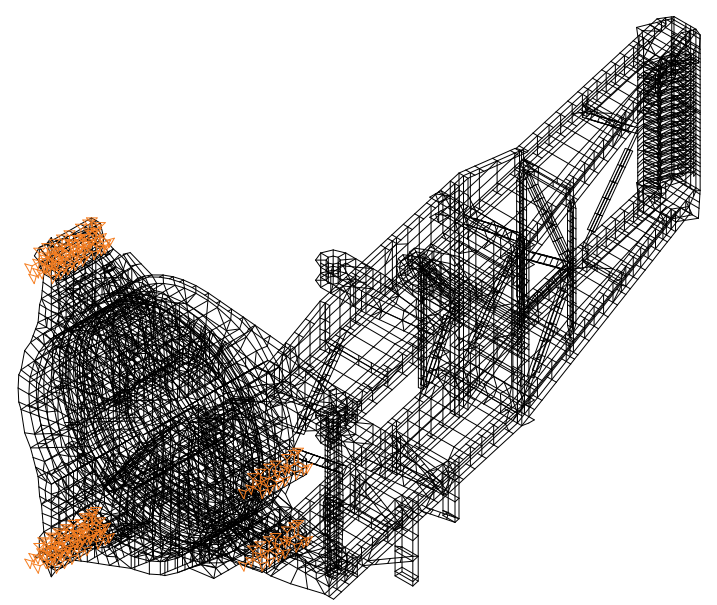

Figure 2 FEM computational model, steel structure (with boundary conditions)

For modelling of the excavator SchRs630 pylons, slewing platform and undercarriage, the previously mentioned software package KOMIPS was used. Taking into account the appearance of the excavator SchRs630 structure, and all the above mentioned in relation to the finite element method, the structure was modelled with a use of plate elements. The whole structure contains 8024 plate elements. Classical plate theory was applied. Axial bearing that connects the slewing platform and undercarriage was built by beam elements (168 beam elements). Although in this case only relevant was pylons construction, slewing platform and undercarriage were built to validate the behaviour of the whole structure (Fig. 2).

Steel structure shown in Fig. 2 is made of steel S355J2G3. The values used in calculations are: modulus of elasticity $210 \mathrm{GPa}$, density $7800 \mathrm{~kg} / \mathrm{m}^{3}$. Other important material property is yield stress, and for this material its value is $355 \mathrm{MPa}$.

\section{STATIC CALCULATION, IDENTIFICATION OF CRACK INITIATION CAUSE}

At first, calculations were made for just two load cases. The first one includes the weight of all the elements that are attached to the pylons and weight of the pylons, slewing platform and undercarriage. The second one also includes all the weights (dead load), but also includes estimated workload in the form of vertical, lateral and frontal force (overall digging force). For both cases kinematic models are made (Fig. 3).

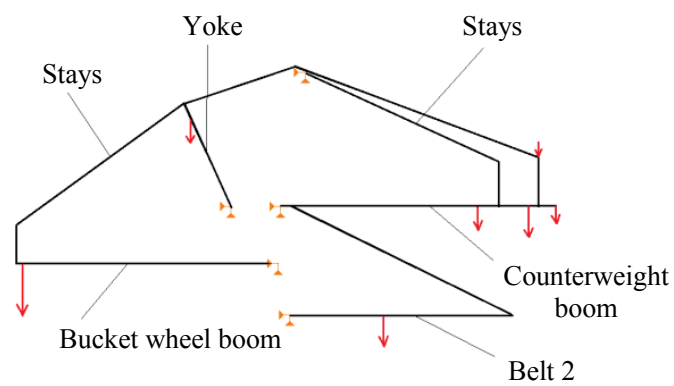

Figure 3 Simplified kinematic model of BWE, the first loading case

The output of those models are reactions in the bearings on pylons (bearing of bucket wheel boom, bearing of counterweight boom etc.), which practically represent loading of pylons (Fig. 4)

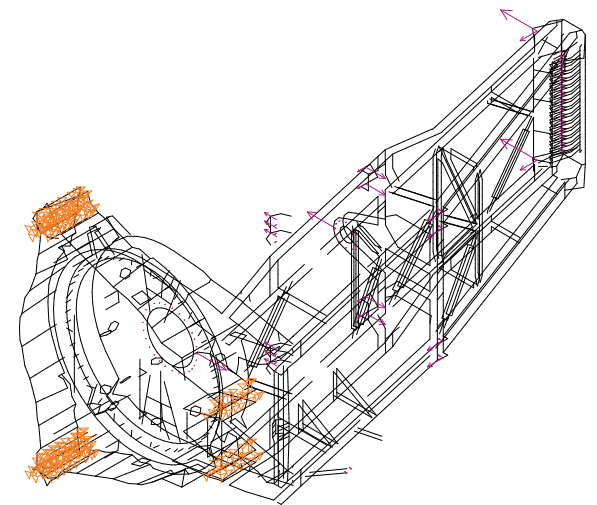

Figure 4 FEM model of BWE, boundary conditions and loads, the first loading case

Computational model for the second load case in relation to this in Fig. 4 differs in the values of the vertical force (in kinematic model vertical digging force is added), 
and in that it contains a lateral force in the bucket wheel boom bearing and a pair of forces (torque) that is applied to pylons. The results of the numerical analysis in the form of the stress field are shown in Fig. 5 and Fig. 6.

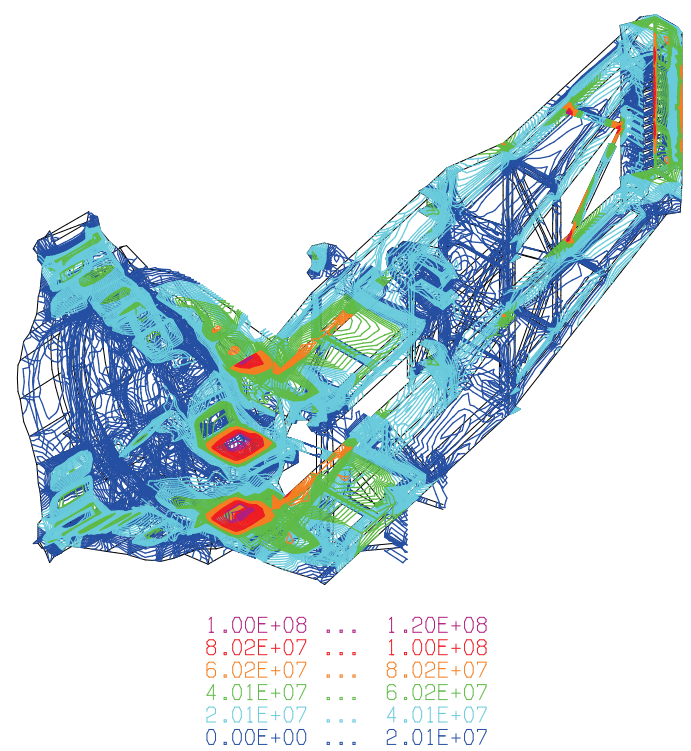

Note: $1.2 \mathrm{e}+8 \mathrm{~N} / \mathrm{m}^{2}$ equals to $120 \mathrm{MPa}$

Figure 5 Von Misses stress, the first loading case
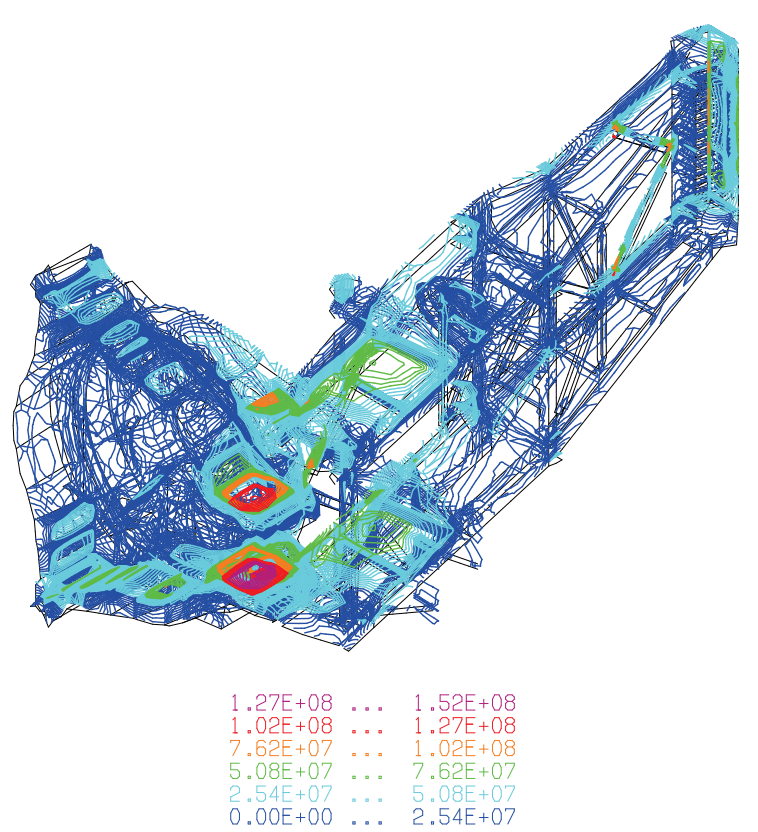

Note: $1.52 \mathrm{e}+8 \mathrm{~N} / \mathrm{m}^{2}$ equals to $152 \mathrm{MPa}$

Figure 6 Von Misses stress, the second loading case

Stress fields are as they are expected to be, on the basis of long-term engineering practice. However, as can be seen (Fig. 5 and Fig. 6) in the zone of crack there is no stress concentration that might be expected to appear. However, based on many years of engineering experience a conclusion was made that the considered gusset plate is loaded the most in case that a pair of forces (torque) tends to shear pylons relatively to each another. It is true that such pair of forces are included in workload (caused by lateral force), but it is obviously not sufficient to cause the appearance of cracks in this place. Other part of the working cycle is fatal in this case. This is the moment of braking the slew drive of the excavator, when, due to the large heavy mass with a large force arm (bucket wheel boom and counterweight boom) large inertial forces are caused. In papers $[15,16]$ authors discussed the influence of bucket wheel boom, as the most loaded part of bucket wheel excavator, to operating status and the whole structure of the excavator.

For this load case (moment of braking the slew drive), magnitudes of inertial forces were estimated and reactions in bearings were calculated (Fig. 7). In addition, in this load case the weight of all the elements that are attached to the pylons and weight of the pylons, slewing platform and undercarriage, were included in calculation.

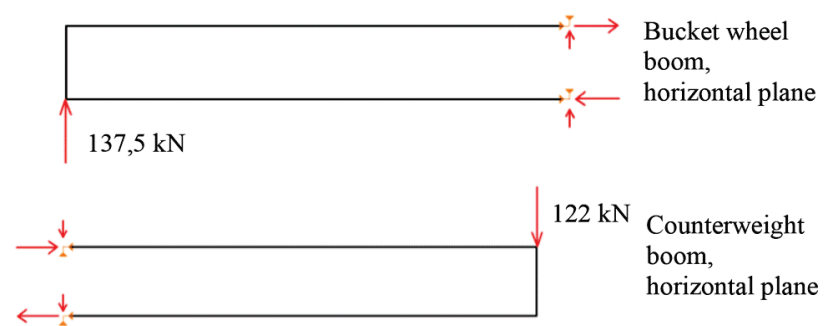

Figure 7 Simplified kinematic model of bucket wheel boom and counterweight boom, horizontal plane, inertial forces

The results of this calculation are shown in Fig. 8 .

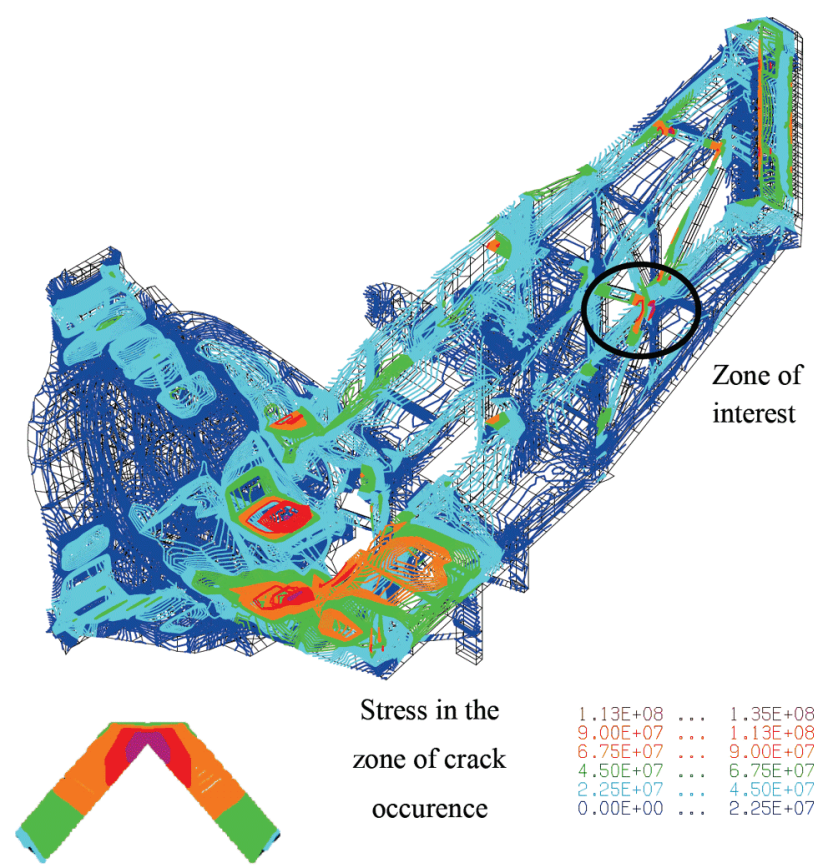

Note: $1.35 \mathrm{e}+8 \mathrm{~N} / \mathrm{m}^{2}$ equals to $135 \mathrm{MPa}$

Figure 8 Von Misses stress, load case including inertial forces caused by slew drive breaking and weights

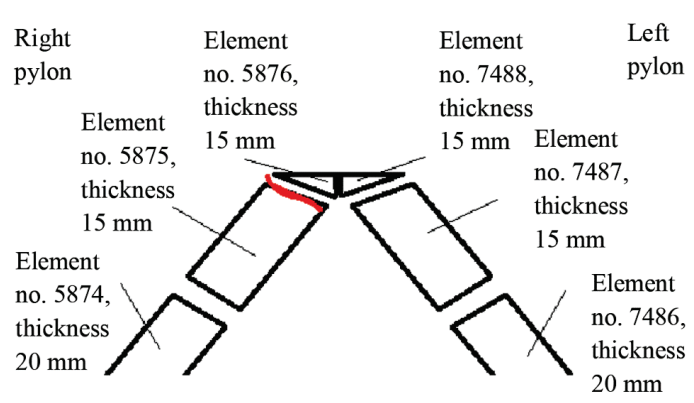

Figure 9 The crack occurrence zone on gusset plate, finite elements and thicknesses 
The crack occurrence zone on gusset plate, finite elements and their thicknesses are shown in Fig. 9. Red line represents the crack.

Tab. 1 shows the values of stresses in finite elements in the zone of the crack.

Table 1 Von Misses stress in finite elements in the zone of the crack

\begin{tabular}{|c|c|c|c|}
\hline \multirow{2}{*}{$\begin{array}{c}\text { Element } \\
\text { no. }\end{array}$} & $\begin{array}{c}\text { The first } \\
\text { load case }\end{array}$ & $\begin{array}{c}\text { The second } \\
\text { load case }\end{array}$ & $\begin{array}{c}\text { The load case including inertial } \\
\text { forces }(137,5 \mathrm{kN} \text { and 122 kN) } \\
\text { caused by slew drive breaking } \\
\text { and weights }\end{array}$ \\
\hline 5875 & 8,382 & 19,29 & 136,9 \\
\hline 5876 & 10,87 & 18,63 & 97,31 \\
\hline 7487 & 9,67 & 19,7 & 139,1 \\
\hline 7488 & 10,2 & 15,34 & 100,3 \\
\hline
\end{tabular}

From Fig. 8 and Tab. 1 can be seen that the stress concentration occurred in the zone of the crack. This means that precisely these forces were the cause of the crack occurrence. However, this stress value is not high enough to cause the cracking. Since the inertial force is impact load, and previously there was an attempt to represent it by the static force, that means that this static force value should be several times higher to accurately represent a real loading influence. Tab. 2 shows the estimation of computational static force value. This force should be high enough to cause a crack in elements 5876 and 7488 (stress higher than a yield stress), and not to cause a crack in elements 5875 and 7487 .

Table 2 Evaluation of static force value that represents a real loading influence (inertial force

\begin{tabular}{|c|c|c|c|c|c|}
\hline \multirow{2}{*}{$\begin{array}{c}\text { Element } \\
\text { no. }\end{array}$} & \multicolumn{5}{|c|}{$\begin{array}{c}\text { Von Misses stress (MPa) for computational force in } \\
\text { horizontal plane several times higher }\end{array}$} \\
\cline { 2 - 6 } & $\begin{array}{c}\text { Two times } \\
\text { higher forces }\end{array}$ & 2,5 & 3 & 3,5 & 3,9 \\
\hline 5875 & 265,4 & 329,7 & $\mathbf{3 9 3 , 9}$ & $\mathbf{4 5 8 , 2}$ & $\mathbf{5 0 9 , 6}$ \\
\hline 5876 & 183,8 & 227 & 270,2 & 313,4 & 348 \\
\hline 7487 & 268,5 & 333,2 & $\mathbf{3 9 8}$ & $\mathbf{4 6 2 , 7}$ & $\mathbf{5 1 4 , 4}$ \\
\hline 7488 & 190,4 & 235,4 & 280,5 & 325,6 & $\mathbf{3 6 1 , 6}$ \\
\hline
\end{tabular}

The stress values higher than the yield stress of the material are highlighted in Tab. 2. When computational forces are assumed to be 3,5 and more times higher, the stress in elements 5876 and 7488 is close to the yield stress of the material. That would cause the crack occurrence in that zone too, which has not happened. That led us to the assumption that computational forces are probably 2,5 to 3 times higher than previously calculated inertial forces.

\section{DYNAMIC CALCULATION, REDESIGN PROPOSITION}

For redesign proposal not to be intuitive, dynamic calculation was performed. Free frequencies and distribution of potential and kinetic energy per oscillating modes are obtained. The reanalysis method presented in the paper [9] was consulted.

For this discussion the third oscillating mode is significant, because it considers torsion of the pylons. The first two modes are not interesting for this discussion, because they consider bending of pylons in two vertical planes. In fact, dynamic calculation gives the assumed behaviour of structures under hypothetical loads acting in specific directions. This means that the third mode represents how the structure behaves under the hypothetical load that tends to shear pylons relatively one to another.

The results of dynamic calculation are shown in Fig 10 and Fig. 11.

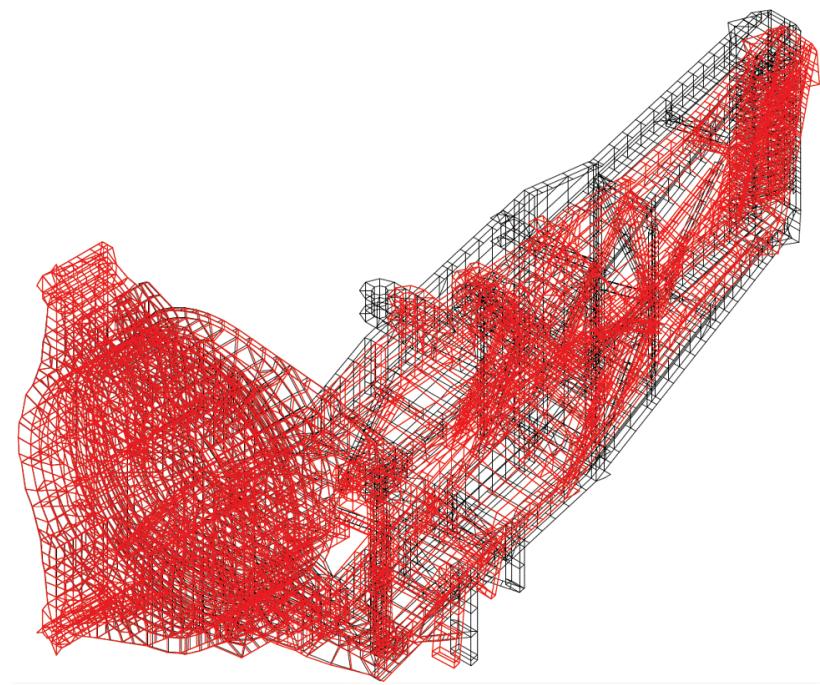

Figure 10 Dynamic calculation, the third oscillating mode, frequency value 5,4 $\mathrm{Hz}$

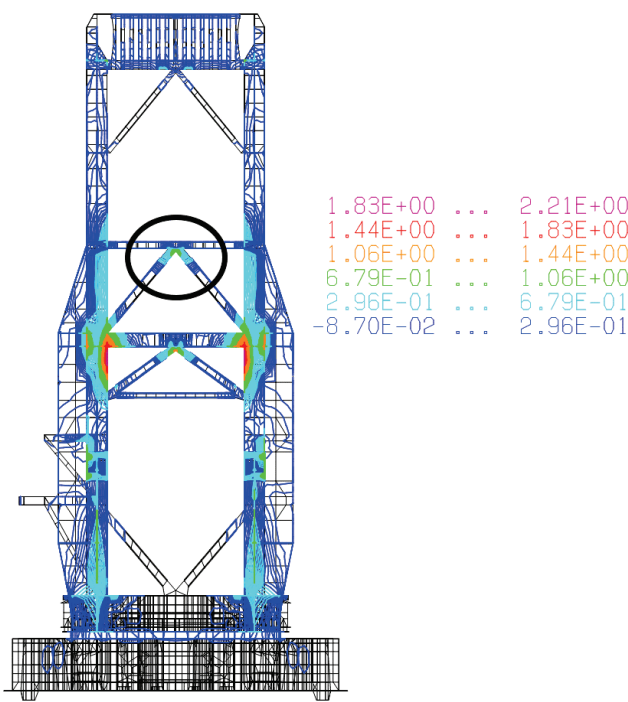

Figure 11 Dynamic calculation, distribution of seizure of potential and kinetic energy, the third oscillating mode

Based on the distribution of seizure of potential and kinetic energy, the spots that can be subjected to redesign are spotted. The goal is to correct the dynamic behaviour of the whole structure, and strength of that part of the structure. It can be seen that the place where the crack occurs was identified as a spot that can be subjected to redesign. Namely, potential energy is higher than the kinetic suggesting that a given element needs to increase rigidity.

The decision was made to increase the thickness of the gusset plates from $15 \mathrm{~mm}$ to $20 \mathrm{~mm}$, which is the thickness of the adjacent elements (5874 and 7487). This decision was made because it is a small intervention and can be performed in a short period of time. Higher increase in thickness of plates was not performed, because 
it leads to different load distribution, and some other elements (plates) may exhibit stress concentrations.

The results of numerical analysis using a thicker gusset plate (after redesign) are shown in Fig. 12 and Tab. 3.

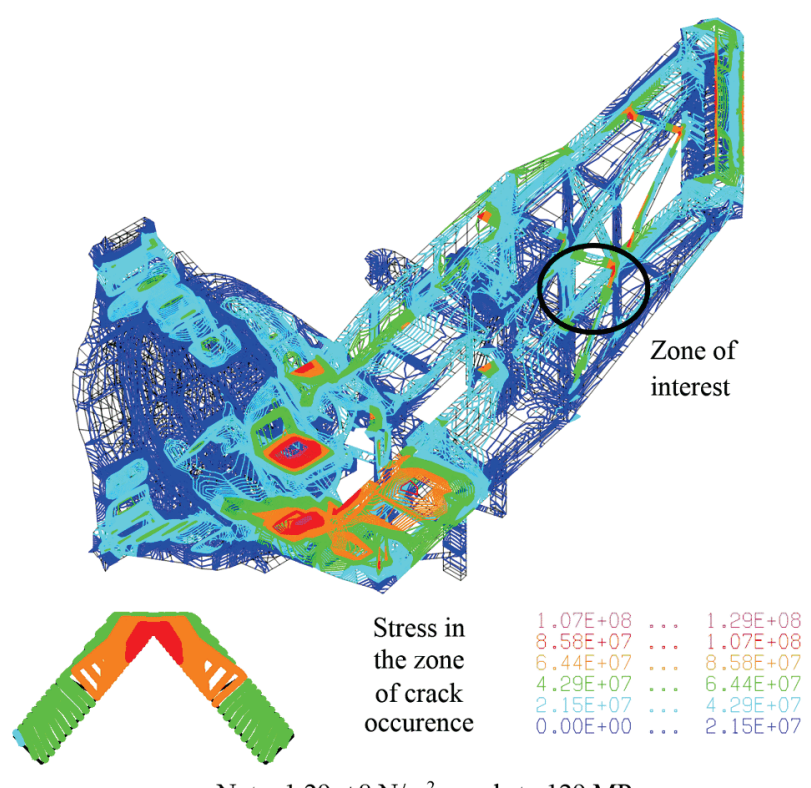

Note: $1.29 \mathrm{e}+8 \mathrm{~N} / \mathrm{m}^{2}$ equals to $129 \mathrm{MPa}$

Figure 12 Von Misses stress, load case including inertial forces caused by slew drive breaking and weights, after redesign of the gusset plate

Table 3 Von Misses stress in finite elements in the zone of the crack, before and after the redesign

\begin{tabular}{|c|c|c|c|c|c|}
\hline \multirow{3}{*}{$\begin{array}{c}\text { Element } \\
\text { no. }\end{array}$} & \multicolumn{4}{|c|}{ Von Misses stress (MPa) } & \multirow{3}{*}{$\begin{array}{c}\text { Stress } \\
\text { reduction } \\
\text { achieved by } \\
\text { redesigning } \\
(\%)\end{array}$} \\
\hline & \multicolumn{2}{|c|}{$\begin{array}{l}\text { Before the } \\
\text { redesign }\end{array}$} & \multicolumn{2}{|c|}{ After the redesign } & \\
\hline & $\begin{array}{l}\text { Forces } \\
\text { of } 137,5 \\
\mathrm{kN} \text { and } \\
122 \mathrm{kN}\end{array}$ & $\begin{array}{l}\text { Three } \\
\text { times } \\
\text { higher } \\
\text { forces }\end{array}$ & $\begin{array}{c}\text { Forces of } \\
137,5 \mathrm{kN} \\
\text { and } 122 \\
\mathrm{kN}\end{array}$ & $\begin{array}{l}\text { Three } \\
\text { times } \\
\text { higher } \\
\text { forces }\end{array}$ & \\
\hline 5875 & 136,9 & 393,9 & 105,9 & 304,7 & 22,64 \\
\hline 5876 & 97,31 & 270,2 & 72,85 & 202,3 & 25,14 \\
\hline 7487 & 139,1 & 398 & 108,1 & 309,3 & 22,29 \\
\hline 7488 & 100,3 & 280,5 & 76,77 & 214,7 & 23,46 \\
\hline
\end{tabular}

It can be concluded that this small intervention resulted in a reduction of stress by more than $20 \%$. Confirmation of this solution is number of cycles in operation without failure after the redesign.

\section{CONCLUSION}

In this paper, in order to solve the problem of a crack occurrence on gusset plate of pylon vertical truss of bucket wheel excavator SchRs630 the following steps were performed:

- a reliable numerical model of the excavator SchRs630 pylons, slewing platform and undercarriage was made,

- numerical calculation for various load cases that represent loading of construction in different moments of working life was carried out,

- the load that causes the stress concentration in gusset plate (crack occurrence) was identified,

- a very simple redesign solution was proposed (thickness of the plate was increased) consulting dynamic calculation and reanalysis method,
- numerical calculation of redesigned structure was performed and stress reduction of more than $20 \%$ is accomplished.

\section{Acknowledgements}

This article is a contribution to the Ministry of Education, Science and Technological Development of the Republic of Serbia funded projects TR35040 and TR35011.

\section{REFERENCES}

[1] Dreyer, E. (1995). Cost-effective prevention of equipment failure in the mining industry. International Journal of Pressure Vessels and Piping, 61(2-3), 329-347. https://doi.org/10.1016/0308-0161(94)00114-X

[2] Bošnjak, S. \& Zrnić, N. (2012). Dynamics, failures, redesigning and environmentally friendly technologies in surface mining systems. Archives of Civil and Mechanical Engineering, 12(3), 348-359. https://doi.org/10.1016/j.acme.2012.06.009

[3] Daničić, D., Maneski, T., \& Ignjatović, D. (2010). Structural diagnostics and behaviour of bucket wheel excavators. Structural integrity and life, 10(1), 53-59.

[4] Maneski, T. \& Ignjatović, D. (2004). Repair and reconstruction of bucket wheel excavators. Structural integrity and life, 4(1), 9-28.

[5] Bošnjak, S., Pantelić, M., Zrnić, N., Gnjatović, N., \& Đorđević, M. (2011). Failure analysis and reconstruction design of the slewing platform mantle of the bucket wheel excavator O\&K SchRs 630. Engineering Failure Analysis, 18(2), 658-669. https://doi.org/10.1016/j.engfailanal.2010.09.035

[6] Maślak, P., Smolnicki, T., \& Pietrusiak, D. (2013). Strain gauges measurements and FEM analysis of elements of chassis of open cast mining machines. Technical Gazette, 20(4), 655-658

[7] Jovančić, P., Ignjatović, D., Tanasijević, M., \& Maneski, T. (2011). Load-bearing steel structure diagnostics on bucket wheel excavator, for the purpose of failure prevention. Engineering Failure Analysis, 18(4), 1203-1211. https://doi.org/10.1016/j.engfailanal.2011.03.001

[8] Rusiński, E., Czmochowski, J., Iluk, A., \& Kowalczyk, M. (2010). An analysis of the causes of a BWE counterweight boom support fracture. Engineering Failure Analysis, 17(1), 179-191. https://doi.org/10.1016/j.engfailanal.2009.06.001

[9] Allaboudi, E., Maneski, T., Trišović, N., \& Ergić, T. (2013). Improving Structure Dynamic Behaviour Using a Reanalysis Procedures Technique. Technical Gazette, 20(2), 297-304.

[10] Deng W. J., Zhang J. Y., Liu L. W., He D., \& Xia W. (2017). Simulation Analysis of a New Chips Recycling Process Termed Forming Extrusion Cutting. International Journal of Simulation Modelling, 16(4), 694-706. https://doi.org/10.2507/IJSIMM16(4)C016

[11] Hamioud, S. \& Khalfallah, S. (2016). Free-vibration of Bernoulli-Euler beam using the spectral element method. Tehnicki glasnik-Technical Journal, 10(3-4), 106-112.

[12] Ismail, M. I. S., \& Afieq, W. M. (2016). Thermal analysis on a weld joint of aluminium alloy in gas metal arc welding. Advances in Production Engineering \& Management, 11(1), 29-37. http://dx.doi.org/10.14743/apem2016.1.207

[13] Sun, W. Q., Guan, J. L., Shao, J., \& He, A. R. (2016). Modelling the Dynamics and Secondary Deformation Behaviour of the Strip with Local Waves in Coiling Process. International Journal of Simulation Modelling, 15(4), 754-765. 
https://doi.org/10.2507/IJSIMM15(4)CO20

[14] Maneski, T. (1998). Computer Modeling and Calculation of Structures, Faculty of Mechanical Engineering, Belgrade, (in Serbian).

[15] Bošković, S., Jovančić, P., Ignjatović, D., Rakićević, B., \& Maneski, T. (2015). Vibration as deciding parameter during revitalization process for replacing the bucket wheel drive. Journal of vibroengineering, 17(1), 24-32.

[16] Brkić, A., Maneski, T., Ignjatović, D., Jovančić, P., \& Spasojević-Brkić, V. (2014). Diagnostics of bucket wheel excavator discharge boom dynamic performance and its reconstruction. Journal of maintenance and reliability, 16(2), 188-197.

\section{Contact information:}

Ana PETROVIĆ, Dr. Sc. Teaching Assistant University of Belgrade,

Faculty of Mechanical Engineering,

Kraljice Marije 16, 11000 Belgrade, Serbia

E-mail: aspetrovic@mas.bg.ac.rs

Taško MANESKI, Dr. Sc. Full Professor

University of Belgrade,

Faculty of Mechanical Engineering,

Kraljice Marije 16, 11000 Belgrade, Serbia

E-mail: tmaneski@mas.bg.ac.rs

Nataša TRIŠOVIĆ, Dr. Sc. Associate Professor University of Belgrade,

Faculty of Mechanical Engineering,

Kraljice Marije 16, 11000 Belgrade, Serbia

E-mail: ntrisovic@mas.bg.ac.rs

Dragan IGNJATOVIĆ, Dr. Sc. Full Professor

University of Belgrade

Faculty of Mining and Geology

Đušina 7

RS-11000 Belgrade, Serbia

E-mail: dragan.ignjatovic@rgf.bg.ac.rs

Momčilo DUNJIĆ, Dr. Sc. Associate Professor

University of Belgrade,

Faculty of Mechanical Engineering,

Kraljice Marije 16, 11000 Belgrade, Serbia

E-mail: mdunjic@mas.bg.ac.rs 